\begin{tabular}{cc|c}
\hline Tar. Bil. Der. & Journal of Agricultural Sciences \\
& $\begin{array}{c}\text { Dergi web sayfası: } \\
\text { www.agri.ankara.edu.tr/dergi }\end{array}$ & Journal homepage: \\
& www.agri.ankara.edu.tr/journal
\end{tabular}

\title{
Mathematical Modelling of Convection Drying Characteristics of Artichoke (Cynara scolymus L.) Leaves
}

\author{
Tuncay GÜNHAN ${ }^{a}$, Vedat DEMİR ${ }^{a}$, Abdülkadir YAĞCIOĞLU ${ }^{a}$ \\ ${ }^{a}$ Ege University, Faculty of Agriculture, Department of Agricultural Machinery, 35100, Bornova, Izmir, TURKEY
}

\section{ARTICLE INFO}

Research Article

DOI: $10.1501 /$ Tarimbil 0000001300

Corresponding Author: Tuncay GÜNHAN, E-mail: tuncay.gunhan@ege.edu.tr, Tel: +90 (232) 3112662

Received: 11 February 2014, Received in Revised Form: 17 March 2014, Accepted: 18 March 2014

\begin{abstract}
This paper presents the results of a study on mathematical modelling of convection drying of artichoke (Cynara scolymus L.) leaves. Artichoke leaves used for drying experiments were picked from the agricultural faculty experimentation fields on the campus area of Ege University. Chopped artichoke leaves were then used in the drying experiments performed in the laboratory at different air temperatures $\left(40,50,60\right.$ and $\left.70{ }^{\circ} \mathrm{C}\right)$ and airflow velocities $\left(0.6,0.9\right.$ and $\left.1.2 \mathrm{~m} \mathrm{~s}^{-1}\right)$ at constant relative humidity of $15 \pm 2 \%$. Drying of artichoke leaves down to $10 \%$ wet based moisture content at air temperatures of $40,50,60$ and $70^{\circ} \mathrm{C}$ lasted about $4.08,2.29,1.32$ and $0.98 \mathrm{~h}$ respectively at a constant drying air velocity of $0.6 \mathrm{~m} \mathrm{~s}^{-1}$ while drying at an air velocity of $0.9 \mathrm{~ms}^{-1}$ took about $3.83,1.60,0.96$ and $0.75 \mathrm{~h}$. Increasing the drying air velocity up to $1.2 \mathrm{~m} \mathrm{~s}^{-1}$ at air temperatures of $40,50,60$ and $70{ }^{\circ} \mathrm{C}$ reduced the drying time down to $3.5,1.54,1.04$ and $0.71 \mathrm{~h}$ respectively. Different mathematical drying models published in the literature were used to compare based on the coefficient of multiple determination $\left(R^{2}\right)$, root mean square error $(R M S E)$, reduced chi-square $\left(\chi^{2}\right)$ and relative deviation modulus $(P)$. From the study conducted, it was concluded that the Midilli et al drying model could satisfactorily explain convection drying of artichoke (Cynara scolymus L.) leaves under the conditions studied.

Keywords: Drying; Artichoke; Modelling
\end{abstract}

\section{Enginar Yapraklarının (Cynara scolymus L.) Konveksiyonel Kuruma Karakteristiklerinin Matematiksel Modellenmesi}

\section{ESER BILGISİ}

Araştırma Makalesi

Sorumlu Yazar: Tuncay GÜNHAN, E-posta: tuncay.gunhan@ege.edu.tr, Tel: +90 (232) 3112662

Geliş Tarihi: 11 Şubat 2014, Düzeltmelerin Gelişi: 17 Mart 2014, Kabul: 18 Mart 2014

\section{ÖZET}

$\mathrm{Bu}$ çalışmada enginar yapraklarının (Cynara scolymus L.) konveksiyonel kuruma karakteristiklerinin matematiksel modellenmesi sunulmuştur. Denemelerde kullanılan enginar yaprakları Ege Üniversitesi yerleşke alanı içerisindeki Ziraat Fakültesi deneme parsellerinden toplanmıştır. Doğranmış enginar yaprakları, laboratuvarda çeşitli sıcaklıklarda $\left(40,50,60\right.$ ve $\left.70{ }^{\circ} \mathrm{C}\right)$ ve hava hızlarında $\left(0.6,0.9\right.$ ve $\left.1.2 \mathrm{~m} \mathrm{~s}^{-1}\right)$ sabit bağ 1 nem değerinde $(\% 15 \pm 2)$ kurutma denemelerinde 
kullanılmıştır. Enginar yapraklarının 40, 50, 60 ve $70{ }^{\circ} \mathrm{C}$ sıcaklıklarda \% 10 nem içeriğine (yb) ulaşmaları $0.6 \mathrm{~m} \mathrm{~s}^{-1} \mathrm{sabit}$ hava hızında sırasıyla yaklaşı olarak 4.08, 2.29, 1.32 ve 0.98 h sürerken, $0.9 \mathrm{~m} \mathrm{~s}^{-1}$ sabit hava hızında yaklaşık olarak $3.83,1.60,0.96$ ve $0.75 \mathrm{~h}$ sürmüştür. $40,50,60$ ve $70{ }^{\circ} \mathrm{C}$ sıcaklıklarda kurutma havası hızını $1.2 \mathrm{~m} \mathrm{~s}^{-1}$ ' ye kadar artırmak kuruma süresini sırasıyla 3.5, 1.54, 1.04 ve 0.71 h'e kadar düşürmüştür. Literatürde yer alan çeşitli kuruma modelleri, belirtme katsayısı $\left(R^{2}\right)$, ortalama hata kareleri karekökü $(R M S E)$, khi-kare $\left(\chi^{2}\right)$ ve mutlak bağıl hata $(P)$ değerleri kullanılarak karşılaştırılmıştır. Yapılan çalışma sonunda denemelerin yapıldığı koşullar altında enginar yapraklarının kurumasını en iyi Midilli vd. kuruma modelinin açıkladı̆̆

Anahtar Kelimeler: Kurutma; Enginar; Modelleme

(C) Ankara Üniversitesi Ziraat Fakültesi

\section{Introduction}

The artichoke (Cynara scolymus L.) is a perennial vegetable that has a great production potential in Europe and in the continent of America and it received a great acceptance for the consumption in recent years in Turkey. Italy, Egypt, Spain, Peru and Argentina are the biggest artichoke producers in the World respectively while Turkey is ranked the $13^{\text {th }}$ one and the production area of artichoke shows an increasing trend in Turkey (FAO 2013).

Among the public, artichoke leaves are known to be useful in eliminating hepatitis and disorders related to hyperlipidemia. Artichoke leaf is also known as an herbal medicine for a long time and used for the treatment of hyperlipidemia and hepatitis in EU traditional folk medicine. Different studies about artichoke have demonstrated their health-protective potential. The artichoke leaves are characterized by the composition and high content in bitter phenolic acids, whose choleretic, hypocholerestemic and hepatoprotector activities are attributed (Alonso et al 2006). Antioxidant, hepatoprotective, anti-HIV, choleretic and inhibiting cholesterol biosynthesis activities of artichoke extracts are also reported by Zhu et al (2005). Shimoda et al (2003) reported that the methanolic extract of artichoke suppress the serum triglyceride in mice. Zhu et al (2005) reported that the artichoke leaves have a new potential application in the treatment of fungal infections. The composition of phytochemicals in artichoke leaves were well documented in the literature and medicinal values of artichoke leaves were found higher than flowers (Sanchez-Rabaneda et al
2003; Bundy et al 2008). Moreover, anti-oxidant, hepatoprotective, lowering blood cholesterol effects were mostly studied in the literature.

Wang et al (2003) used three different artichoke varieties in order to determine the phenolic acid components. They dried the artichoke leaves and tissues in an oven at 70 ${ }^{\circ} \mathrm{C}$ and also in a freeze drier. After the drying, samples were kept in air tight bags at room temperatures for further analysis. Researchers determined the phenolic acid compounds and amounts by HPLC analysis for mature leaves, young and mature artichoke heads. According to the results obtained by Wang et al (2003) it was reported that the leaves have highest total phenols content than young artichoke heads as followed by mature artichoke heads. In terms of the method they used, they concluded that freeze drying and air assisted drying did not affect the amount of phenolic acid in artichoke.

Fresh food materials cannot be stored for a long time. Therefore, products must be dried for a long-term storage. One of the most traditional and extensive technique used for the production of dehydrated fruits and vegetables is convection drying (Nicoleti et al 2001). It allows to reduce mass and volume, to store the products under ambient temperature and to minimize packaging, transportation and storage cost (Baysal et al 2003).

Mathematical modelling in drying studies is one of the most significant step in drying technology and allows engineers to select the most suitable drying 
conditions and to form a drying equipment at a proper scale (Strumillo \& Kudra 1986; Hawlader et al 1997).

Scientific studies on the drying process of artichoke leaves in the literature is very limited and the most of them focused on determination of the chemical components of artichoke leaves and there is no study published on the determination of the drying characteristics of the artichoke leaves.

The aim of the study was to determine the drying characteristics and to develop a mathematical model for predicting the kinetics of convection drying of artichoke leaves.

\section{Material and Methods}

\subsection{Experimental procedures}

Drying experiments were performed in a laboratory scale convective hot air dryer constructed in the Department of Agricultural Machinery, Faculty of Agriculture, Ege University, Izmir, Turkey. A schematic diagram of the laboratory dryer is illustrated in Figure 1. The drying system used in this study has been described in details by Demir et al (2007). The laboratory dryer includes; fan, cooler, heater, humidifier, drying unit and automatic control unit.

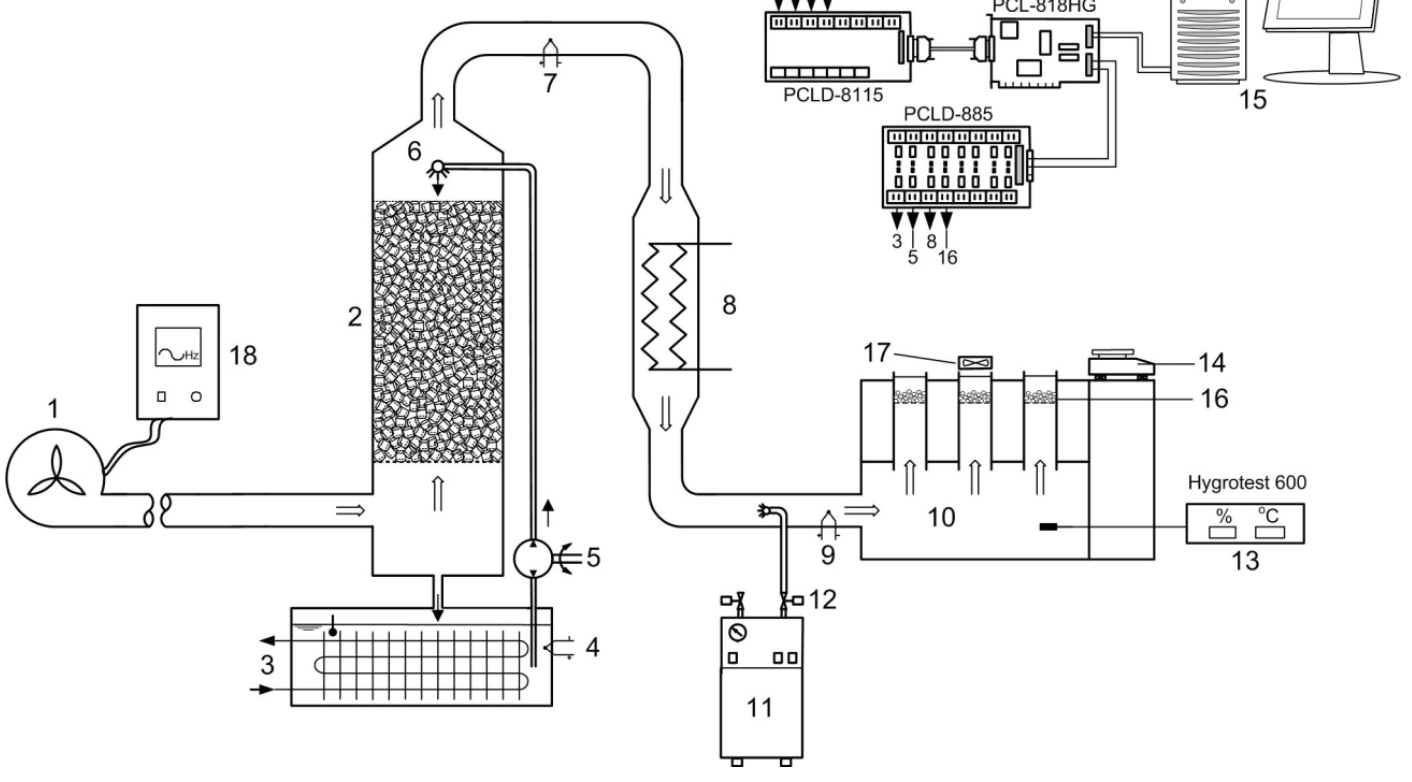

Figure 1- Schematic diagram of the drying unit: 1 , centrifugal fan; 2 , cooling and condensing tower; 3 , cold water tank and evaporator; 4,7,9, thermocouples (type T); 5 , circulation pump; 6 , cold water shower; 8 , electric heaters; 10, mixing chamber and air channels; 11 , steam tank; 12 , solenoid valve; 13 , temperature $\&$ humidity sensor; 14 , balance; 15 , computer with data acquisition and control cards; 16 , artichoke leaves; 17, anemometer; 18, frequency converter

Şekil 1- Kurutma ünitesinin şematik çizimi; 1, santrifüj fan; 2, soğutma ve yoğuşturma kulesi; 3, soğuk su tank ve evaparatör; 4,7,9, termokupl (T tipi); 5, sirkülasyon pompası; 6, soğuk su duşu; 8, elektrikli ısitıcl; 10, karışım odası ve hava kanallarl; 11, buhar tankl; 12, solenoid valf; 13, stcakllk ve nem sensörü; 14, terazi; 15, veri aklş ve kontrol kartlı bilgisayar; 16, enginar yapraklarl; 17, anemometre; 18, frekans dönüştürücü 
A personal computer equipped with A/D converters cards and data acquisition \& control software called VisiDAQ (Advantech Automation Corp., USA) was used to control the drying temperature, relative humidity and the automation of the drying system.

The artichoke leaves for the drying experiments were picked from the middle branches of the artichoke plants as they are located on the campus area of Ege University, between 8:30 and 9:00 a.m. During the experiments, the fresh leaves were collected daily in early-morning and unblemished ones were picked and used in the drying experiments.

Some preliminary tests were carried out to examine the drying conditions from the point of test stand and some expected changes in artichoke leaves. In these tests, a homogeneous drying of the whole leaves was not obtained, especially the main vein of the leaves was found to be the last part that dried. In this situation, the tissues in the thinner part of the leaves were subjected to over drying and drying time significantly increased. For this reason, the leaves were divided into two parts along the main vein and then sliced perpendicularly to the main vein. The 4 or $5 \mathrm{~mm}$ wide slices were then used for the drying process.

The experiments conducted in the lab had the objective to determine the effect of air temperature and drying airflow velocity on the drying constant were achieved at temperatures of 40, 50, 60 and $70{ }^{\circ} \mathrm{C}$, and at velocity of $0.6,0.9$ and $1.2 \mathrm{~m} \mathrm{~s}^{-1}$ respectively. During the experiments, the relative humidity was maintained at $15 \pm 2 \%$. The drying system was run for at least one hour to maintain steady-state conditions before the experiments. Each drying experiment was performed with 20 $\mathrm{g}$ of leaves after steady state conditions of both temperature and air velocity was achieved in the dryer. The artichoke leaves were placed in a vertical drying channel equipped with fine sieves and weighed every three minutes in the first 15 minute drying process and then every 5 minutes until the drying process is completed. The drying experiments were ended when the mass of the samples does not change.

The leaf samples were kept in an air-circulated oven for 24 hours at $105 \pm 2{ }^{\circ} \mathrm{C}$ in order to determine the initial moisture content. All of these experiments mentioned above were triplicated.

\subsection{Mathematical modelling of the drying curves}

The experimental moisture ratio data of artichoke leaves were fitted to semi-empirical models in Table 1 to define the convection drying kinetics. The models in Table 1 were widely employed to describe the convection drying kinetics of vegetables.

Table 1- Mathematical models widely used to describe the convection drying kinetics

Çizelge 1- Konveksiyonla kuruma kinetiklerini belirlemede yaygın olarak kullanılan matematiksel modeler

\begin{tabular}{lll}
\hline Model name & Model equation & References \\
\hline Lewis & $M R=\exp (-k t)$ & Yaldız \& Ertekin (2001) \\
Page & $M R=\exp \left(-k t^{n}\right)$ & Alibaş (2012) \\
Modified Page & $M R=\exp \left[-(k t)^{n}\right]$ & Artnaseaw et al (2010) \\
Henderson and Pabis & $M R=a \exp (-k t)$ & Figiel (2010) \\
Logarithmic & $M R=a \exp (-k t)+c$ & Doymaz (2013) \\
Midilli et al & $M R=a \exp \left(-k t^{n}\right)+b t$ & Silva et al (2011) \\
Demir et al & $M R=a \exp \left[-(k t)^{n}\right]+b$ & Demir et al (2007) \\
\hline
\end{tabular}

$M R$, moisture ratio; $a, b, c$ coefficients; $n$, drying exponent specific to each equation; $k$, drying coefficients specific to each equation; $t$, time 
The left hand side of the equations is a dimensionless number known as moisture ratio $M R$ and it could be written as follows:

$$
M R=\frac{M_{t}-M_{e}}{M_{0}-M_{e}}
$$

The moisture ratio was calculated using equation (1), which was simplified to equation (2) by some investigators (Menges \& Ertekin, 2006; Midilli \& Kucuk 2003; Sacilik \& Elicin 2006; Togrul \& Pehlivan 2003; Yaldiz et al 2001) because of the $M_{e}$ is relatively small when compared to $M_{0}$ and the deviation of the relative humidity of the drying air during the processes.

$$
M R=\frac{M_{t}}{M_{o}}
$$

MS Excel software was used for the calculation of the drying constants and coefficients of semiempirical drying models in Table 1. The coefficient of multiple determination $\left(R^{2}\right)$ was considered as the main criteria for selecting the best model to obtain the convection drying curves of artichoke leaves. Besides the $R^{2}$, some other statistical tests were achieved in order to evaluate how the developed models fit to the data obtained from the experiments. Among these, root mean square error (RMSE) and reduced chi-square $\left(\chi^{2}\right)$ have a common use in drying related studies (Krokida et al 2002; Yaldiz \& Ertekin 2001; Midilli \& Kucuk 2003; Akgun \& Doymaz 2005). In addition to these methods, mean relative deviation modulus $(P)$ value was also used to evaluate the goodness of fit of the models (Sacilik \& Elicin 2006; Özdemir \& Devres 1999). These test functions used to determine the best fit are given below:

$$
\begin{aligned}
& R M S E=\sqrt{\frac{1}{N} \sum_{i=1}^{N}\left(M R_{p r e, i}-M R_{\text {exp }, i}\right)^{2}} \\
& \chi^{2}=\frac{\sum_{i=1}^{N}\left(M R_{\text {exp }, i}-M R_{p r e, i}\right)^{2}}{N-n_{1}} \\
& P=\frac{100}{N} \sum \frac{\left|M R_{\text {exp }, i}-M R_{p r e, i}\right|}{M R_{\text {exp }, i}}
\end{aligned}
$$

The better goodness of the fit means that the value of $R^{2}$ should be higher while the value of RMSE, $\chi^{2}$ and $P$ should be lower. Selection of the best suitable drying model was done using this criteria. The drying constants $(k)$ of the chosen model were then related to the multiple combinations of the different equations as in the form of linear, polynomial, logarithmic, power, exponential and Arrhenius.

\section{Results and Discussion}

Drying of the artichoke leaves was performed in a convective drier and the experiments were carried out at four different temperatures $(40,50,60$ and $\left.70{ }^{\circ} \mathrm{C}\right)$, and three drying air velocities $(0.6,0.9$ and $1.2 \mathrm{~m} \mathrm{~s}^{-1}$ ) and constant air relative humidity $(15 \pm 2 \%)$. The average initial moisture content of the artichoke leaves was $4.8964 \mathrm{~kg}$ water $\mathrm{kg}^{-1}$ $\mathrm{dm}$ and the leaves was dried to the average final moisture content of $0.0662 \mathrm{~kg}$ water $\mathrm{kg}^{-1} \mathrm{dm}$ until no changes in the mass of leaves were obtained. The characteristic drying curves were constructed from the experimental data and indicated that there is only a falling rate drying period for all experimental cases. The changes in the moisture ratio versus drying time and the drying rate versus drying time for temperatures and airflow velocity studied is presented in Figure 2, and Figure 3 respectively.

From these figures it is clear that the moisture ratio of artichoke leaves decreases continuously with drying time. As seen from Figure 2, it is obvious that the main factors effecting the drying kinetics of artichoke leaves are the drying air temperature and drying airflow velocity. Drying time went down as the drying air temperature and airflow velocity increases. Drying air temperature was reported to be the most important factor influencing drying rate by many researchers. Using higher drying temperatures increases drying rate significantly (Temple \& van Boxtel 1999; Panchariya et al 2002). Drying of artichoke leaves down to $10 \%$ wet based moisture content at air temperatures of $40,50,60$ and $70{ }^{\circ} \mathrm{C}$ lasted about 

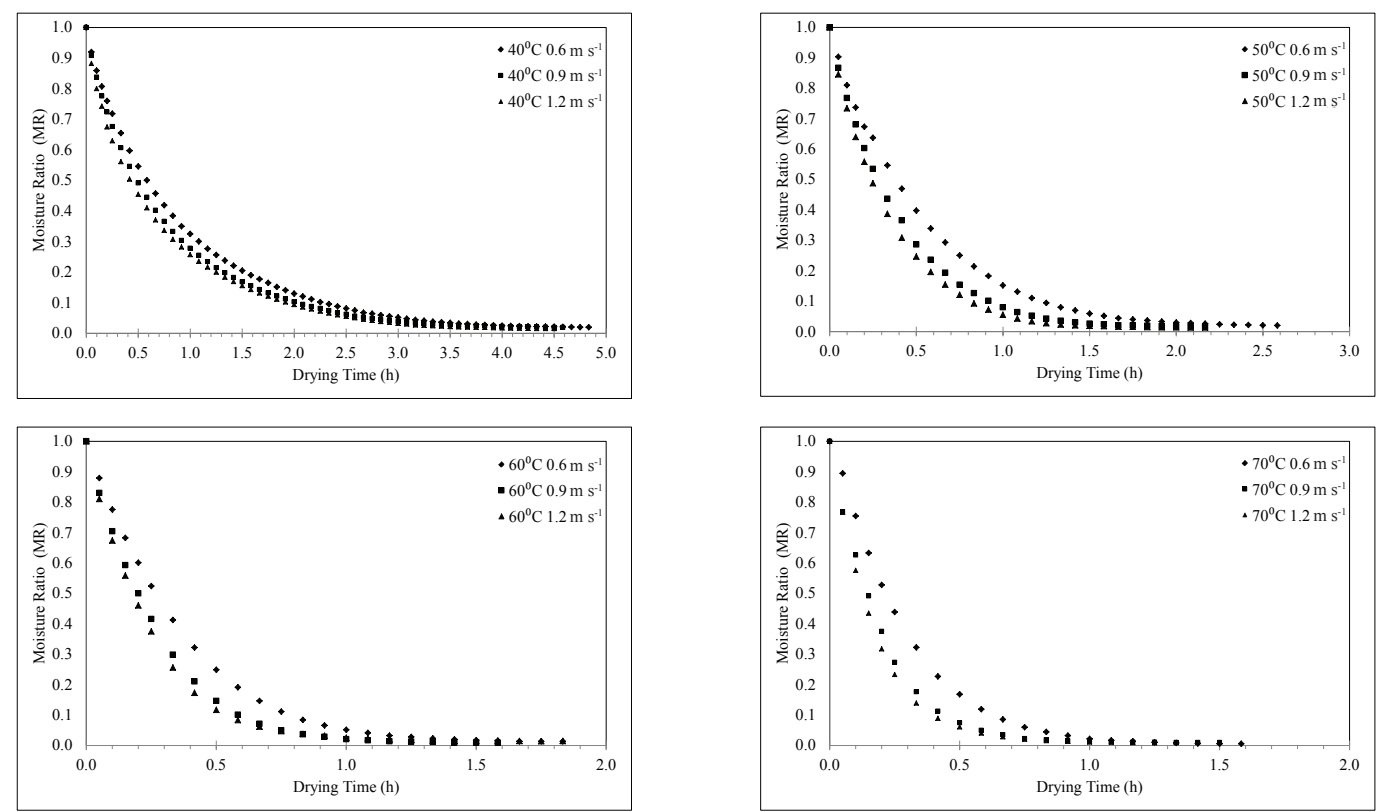

Figure 2- Variations of moisture ratio as a function of time for different air-drying temperatures and velocities Şekil 2- Kurutma havasının farklı sıcaklık ve hızlarında nem oranının zamana göre değişimleri
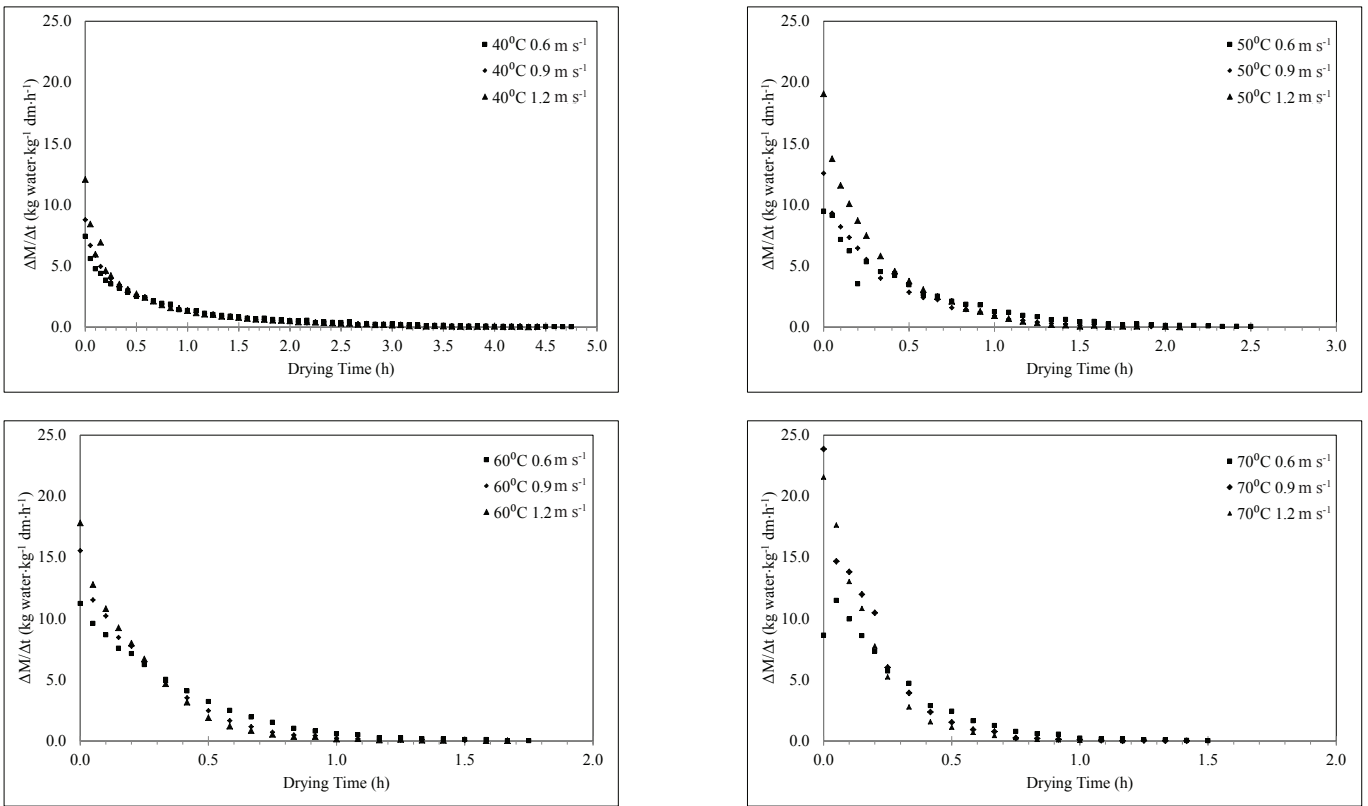

Figure 3 - Variations of drying rate as a function of time for different air-drying temperatures and velocities Şekil 3 - Kurutma havasının farklı sıcaklık ve hızlarında kuruma hızının zamana göre değisşimleri 
$4.08,2.29,1.32$ and $0.98 \mathrm{~h}$ respectively at a constant drying air velocity of $0.6 \mathrm{~m} \mathrm{~s}^{-1}$ while drying at an air velocity of $0.9 \mathrm{~m} \mathrm{~s}^{-1}$ took about $3.83,1.60,0.96$ and $0.75 \mathrm{~h}$. Increasing the drying air velocity up to $1.2 \mathrm{~m} \mathrm{~s}^{-1}$ at air temperatures of $40,50,60$ and $70{ }^{\circ} \mathrm{C}$ reduced the drying time down to $3.5,1.54$, 1.04 and $0.71 \mathrm{~h}$ respectively. From these findings it could be stated that drying time for artichoke leaves at $70{ }^{\circ} \mathrm{C}$ was 4.9 times shorter than that of $40{ }^{\circ} \mathrm{C}$. The experimental data showed that there is no constant drying rate period (Figure 3 ). The drying process of artichoke leaves during all of the tests took place in the falling rate period. As seen from Figure 3, the drying rate increases while the time is shortened as the drying air temperature and the velocity increases. The main factor that causes this is the temperature of the drying air as followed by velocity. The effect of either 1.2 or $0.9 \mathrm{~m} \mathrm{~s}^{-1}$ air velocity in all of the drying tests was similar and increasing the air velocity above $1.0 \mathrm{~m} \mathrm{~s}^{-1}$ did not increase the drying rate too much.

The moisture content data obtained from the experiments were converted to the moisture ratio values and then curve fitting calculations were performed on the drying models as tabulated in Table 1. These models and the results of the statistical analyses are shown in Table 2.

The coefficient of multiple determination $\left(R^{2}\right)$ indicating the goodness of the fit is over the values of 0.99395 in all drying conditions. Root mean square error (RMSE) which gives the deviation between the predicted and experimental values is in the range of 0.001413 and 0.021848 in the all drying conditions. The reduced chi-square $\left(\chi^{2}\right)$ is in the range of 0.000002 and 0.001032 in all drying conditions. The mean relative deviation modulus $(P)$ values were found in the range of 1.495 and 39.388 in the all drying conditions. The statistical analysis results of experiments generally indicate high correlation coefficients for the all drying models. The highest values of $R^{2}$ and the lowest values of RMSE, $\chi^{2}$ and $P$ can be obtained by using the Demir et al and Midilli et al models in all drying air temperatures and velocities. When the Midilli et al model used, it can be achieved the higher values than 0.99941 for $R^{2}$, lower values than 0.00485 for $R M S E$, lower values than 0.00025 for $\chi^{2}$ and lower values than 7.202 for $P$. Therefore, the Midilli et al model was preferred because of its better fit to drying data. The Midilli et al model has the following form and can reveal satisfactory results in order to predict the experimental values of the moisture ratio values for artichoke leaves.

$$
M R=a \cdot \exp \left(-k t^{n}\right)+b t
$$

The statistical based results as obtained by Midilli et al model were tabulated in Table 3. As seen from the table, the drying constant $k$ increases once the temperature of the drying air and velocity increases while the other model constants, $a, n$ and $b$ fluctuate.

Some other regression analysis were also made in order to consider the effect of the drying air temperature and velocity variables on the drying constant $k\left(\mathrm{~h}^{-1}\right)$ of the Midilli et al model. The drying constants $(k)$ were correlated to the drying air temperature and velocity by considering the different combinations of the equations as in the form of simple linear, polynomial, logarithmic, power, exponential and Arrhenius type using the software Datafit 6.0 (Oakdale Engineering). The power model was assumed to be the appropriate model due to the easiness in use even though some higher order polynomial functions produced better predictions.

$$
k=A \cdot T^{B} \cdot V^{C}
$$

In model, $T$ is temperature $\left({ }^{\circ} \mathrm{C}\right), V$ is the drying air velocity $\left(\mathrm{m} \mathrm{s}^{-1}\right), A, B$ and $C$ are constants. The fitting to the above written model, the coefficients, $A, B$ and $C$ was found to be $0.0002048,2.408351$ and 0.563268 , respectively with a coefficient of determination of $97.829 \%$. The experimental and predicted drying constant $(k)$ of the Midilli et al model by use of the developed model is compared and the findings from the comparison are depicted in Figure 4. 
Table 2- Statistical analysis of drying models at various drying air temperatures and velocities Çizelge 2- Kurutma havasının farklı sıcaklık ve hızları için kuruma modellerinin istatistiksel analizi

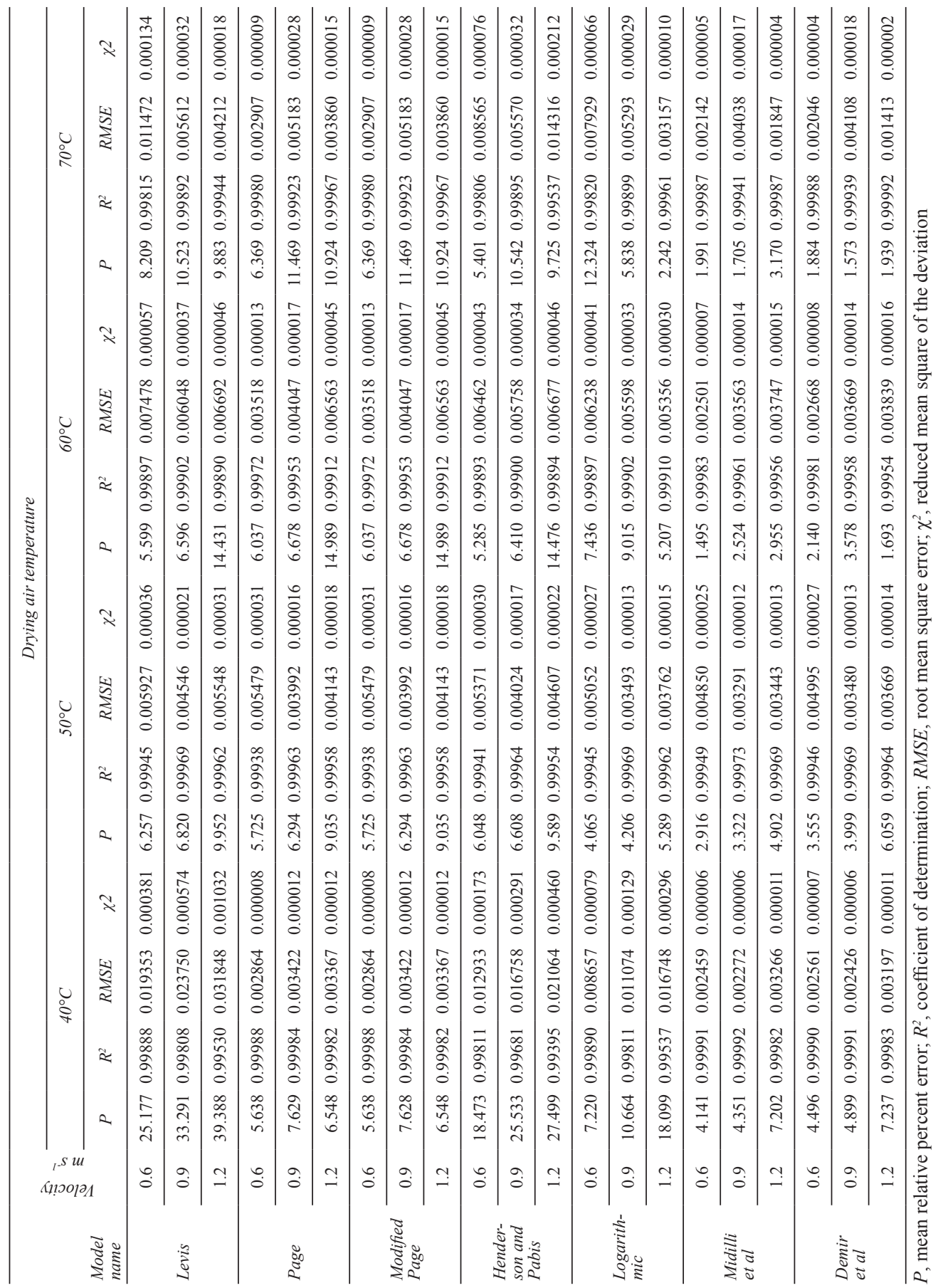


Table 3- Statistical results of the Midilli et al model and its constants and coefficients at different drying conditions

Çizelge 3- Kurutma havasının farklı sıcaklık ve hızları için Midilli vd modelinin sabitleri, katsayıları ve istatistik analizi

\begin{tabular}{|c|c|c|c|c|c|c|c|c|c|c|}
\hline 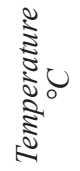 & $\frac{.}{\tilde{D}}=$ & 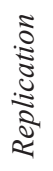 & $k$ & $a$ & $n$ & $b$ & $P$ & $R^{2}$ & RMSE & $\chi^{2}$ \\
\hline \multirow{9}{*}{40} & \multirow{3}{*}{0.6} & 1 & 1.112265 & 0.994631 & 0.883051 & 0.000700 & 4.628 & 0.999894 & 0.002674 & $7.653 \mathrm{E}-06$ \\
\hline & & 2 & 1.148662 & 0.996646 & 0.875175 & 0.001010 & 4.671 & 0.999890 & 0.002711 & $7.865 \mathrm{E}-06$ \\
\hline & & 3 & 1.094725 & 0.996981 & 0.899273 & 0.000900 & 3.304 & 0.999919 & 0.002364 & $5.980 \mathrm{E}-06$ \\
\hline & \multirow{4}{*}{0.9} & 1 & 1.249831 & 0.998437 & 0.862140 & 0.001325 & 4.916 & 0.999901 & 0.002557 & $7.020 \mathrm{E}-06$ \\
\hline & & 2 & 1.329317 & 1.002016 & 0.851355 & 0.001509 & 4.321 & 0.999920 & 0.002272 & $5.545 \mathrm{E}-06$ \\
\hline & & 3 & 1.273962 & 1.001094 & 0.849801 & 0.001481 & 3.909 & 0.999923 & 0.002226 & $5.324 \mathrm{E}-06$ \\
\hline & & 1 & 1.356235 & 0.998106 & 0.788721 & -0.000587 & 7.491 & 0.999824 & 0.003269 & $1.150 \mathrm{E}-05$ \\
\hline & \multirow[t]{2}{*}{1.2} & 2 & 1.413097 & 1.001369 & 0.786712 & -0.000040 & 6.728 & 0.999854 & 0.002949 & $9.353 \mathrm{E}-06$ \\
\hline & & 3 & 1.320560 & 0.998131 & 0.796229 & -0.000756 & 7.436 & 0.999665 & 0.004546 & $2.223 \mathrm{E}-05$ \\
\hline \multirow{9}{*}{50} & \multirow{3}{*}{0.6} & 1 & 1.834230 & 0.985748 & 1.010571 & 0.002182 & 3.613 & 0.999396 & 0.005310 & $3.018 \mathrm{E}-05$ \\
\hline & & 2 & 1.913430 & 0.987839 & 1.019477 & 0.003203 & 3.159 & 0.999450 & 0.005069 & $2.749 \mathrm{E}-05$ \\
\hline & & 3 & 1.854856 & 0.989230 & 1.007723 & 0.003885 & 2.213 & 0.999577 & 0.004427 & 2.097E-05 \\
\hline & \multirow{4}{*}{0.9} & 1 & 2.512386 & 0.992101 & 1.005202 & 0.003502 & 3.044 & 0.999823 & 0.002656 & $7.547 \mathrm{E}-06$ \\
\hline & & 2 & 2.529225 & 0.988270 & 1.002063 & 0.002949 & 4.240 & 0.999275 & 0.005345 & $3.057 \mathrm{E}-05$ \\
\hline & & 3 & 2.465516 & 0.992277 & 1.004665 & 0.003752 & 2.828 & 0.999833 & 0.002581 & 7.127E-06 \\
\hline & & 1 & 2.851674 & 0.992316 & 0.984463 & 0.002619 & 5.036 & 0.999742 & 0.003127 & $1.046 \mathrm{E}-05$ \\
\hline & \multirow[t]{2}{*}{1.2} & 2 & 2.859636 & 0.989110 & 0.981150 & 0.003525 & 5.682 & 0.999515 & 0.004261 & $1.943 \mathrm{E}-05$ \\
\hline & & 3 & 2.747172 & 0.992062 & 0.989060 & 0.003475 & 4.119 & 0.999760 & 0.003035 & $9.858 \mathrm{E}-06$ \\
\hline \multirow{9}{*}{60} & \multirow{3}{*}{0.6} & 1 & 2.881234 & 0.990799 & 1.108364 & 0.003324 & 2.150 & 0.999805 & 0.002744 & $8.058 \mathrm{E}-06$ \\
\hline & & 2 & 3.324264 & 0.990232 & 1.125468 & 0.005456 & 1.556 & 0.999780 & 0.002872 & $8.829 \mathrm{E}-06$ \\
\hline & & 3 & 2.854406 & 0.992319 & 1.083662 & 0.004832 & 1.268 & 0.999844 & 0.002423 & $6.283 \mathrm{E}-06$ \\
\hline & \multirow{4}{*}{0.9} & 1 & 3.808960 & 0.989667 & 1.086432 & 0.003214 & 2.710 & 0.999644 & 0.003418 & $1.250 \mathrm{E}-05$ \\
\hline & & 2 & 4.264571 & 0.990612 & 1.080361 & 0.005065 & 1.895 & 0.999582 & 0.003628 & $1.408 \mathrm{E}-05$ \\
\hline & & 3 & 3.994963 & 0.988930 & 1.082727 & 0.002063 & 3.747 & 0.999506 & 0.003998 & $1.710 \mathrm{E}-05$ \\
\hline & & 1 & 4.171691 & 0.994334 & 1.065097 & 0.009271 & 3.001 & 0.999719 & 0.003044 & $9.915 \mathrm{E}-06$ \\
\hline & \multirow[t]{2}{*}{1.2} & 2 & 4.833548 & 0.991000 & 1.070963 & 0.008885 & 3.099 & 0.999403 & 0.004313 & $1.991 \mathrm{E}-05$ \\
\hline & & 3 & 4.123418 & 0.991314 & 1.037263 & 0.008903 & 2.693 & 0.999487 & 0.004050 & $1.755 \mathrm{E}-05$ \\
\hline \multirow{9}{*}{70} & \multirow{3}{*}{0.6} & 1 & 4.042290 & 1.007230 & 1.137207 & 0.000496 & 2.847 & 0.999823 & 0.002496 & $6.667 \mathrm{E}-06$ \\
\hline & & 2 & 4.367799 & 1.004047 & 1.163435 & 0.002166 & 4.797 & 0.999929 & 0.001577 & $2.660 \mathrm{E}-06$ \\
\hline & & 3 & 3.685662 & 1.008259 & 1.125381 & 0.007454 & 1.552 & 0.999812 & 0.002564 & 7.033E-06 \\
\hline & \multirow{3}{*}{0.9} & 1 & 5.579094 & 0.993387 & 1.061496 & 0.006544 & 1.717 & 0.999348 & 0.004244 & $1.928 \mathrm{E}-05$ \\
\hline & & 2 & 5.659406 & 0.992359 & 1.081631 & 0.007641 & 1.920 & 0.999284 & 0.004473 & $2.141 \mathrm{E}-05$ \\
\hline & & 3 & 5.200341 & 0.994378 & 1.032644 & 0.007303 & 1.472 & 0.999568 & 0.003447 & $1.272 \mathrm{E}-05$ \\
\hline & \multirow{3}{*}{1.2} & 1 & 6.017516 & 1.000903 & 1.046930 & 0.007840 & 3.222 & 0.999891 & 0.001678 & $3.013 \mathrm{E}-06$ \\
\hline & & 2 & 6.342867 & 1.001279 & 1.052964 & 0.010255 & 2.994 & 0.999821 & 0.002136 & $4.881 \mathrm{E}-06$ \\
\hline & & 3 & 6.137372 & 1.001025 & 1.035744 & 0.008883 & 3.571 & 0.999861 & 0.001877 & $3.769 \mathrm{E}-06$ \\
\hline
\end{tabular}




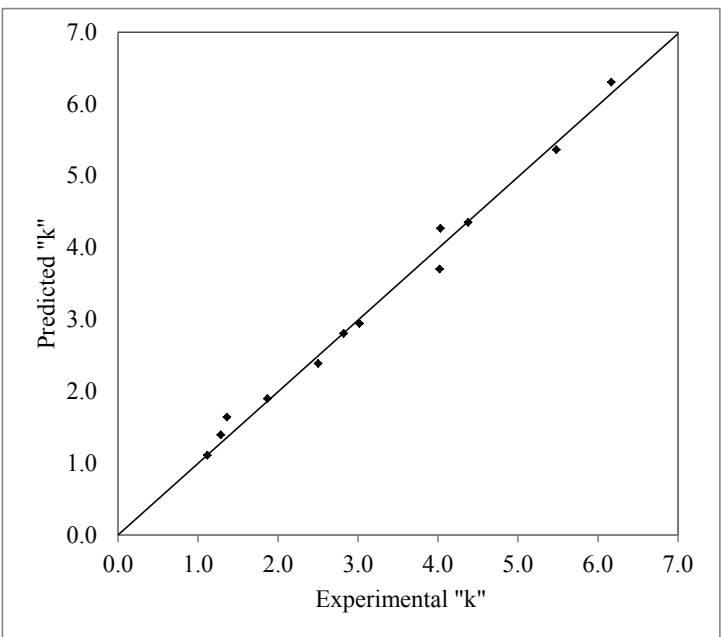

Figure 4- Comparison of the experimental and predicted drying constant $(k)$ of the Midilli et al model

Şekil 4-Midilli vd modelindeki kuruma katsayısinin ( $k$ ) deneysel ve tahminlenen değerler ile karşılaş̧ırılması

$$
k=0.0002048 \cdot T^{2.408351} \cdot V^{0.563268}\left(R^{2}=0.97829\right)(8)
$$

The drying constant, $k$ was employed in model developed by Midilli et al and predictions were made. For this purpose, regression analysis were made and the predicted results were correlated with the experimental data in order to obtain a higher $R^{2}$ while reducing the RMSE and $\chi^{2}$ and the values of a, $\mathrm{n}$ and $\mathrm{b}$ were found to be $0.983970,1.039708$ and 0.0074083 respectively.

The Midilli et al model as a function of the temperature of drying air and velocity in order to use for artichoke drying has the following form:

$$
\begin{aligned}
M R= & 0.983970 \cdot \exp \left[-\left(0.0002048 \cdot T^{2.408351} \cdot V^{0.563268}\right)\right. \\
& \left.\cdot t^{1.039708}\right]+0.0074083 \cdot t\left(R^{2}=0.992995\right)
\end{aligned}
$$

The generalised drying model is valid under the following conditions of air temperature $(T)$ and air velocity $(V)$.

$$
40^{\circ} \mathrm{C} \leq T \leq 70^{\circ} \mathrm{C} \quad 0.6 \mathrm{~ms}^{-1} \leq V \leq 1.2 \mathrm{~ms}^{-1}
$$

The dimensionless moisture ratio values found from experimental data and predicted models are depicted in Figure 5. As seen from this figure, the predicted values generally accumulate around the straight line. This indicates how the developed model fits to the data obtained in the laboratory for the drying of artichoke leaves.

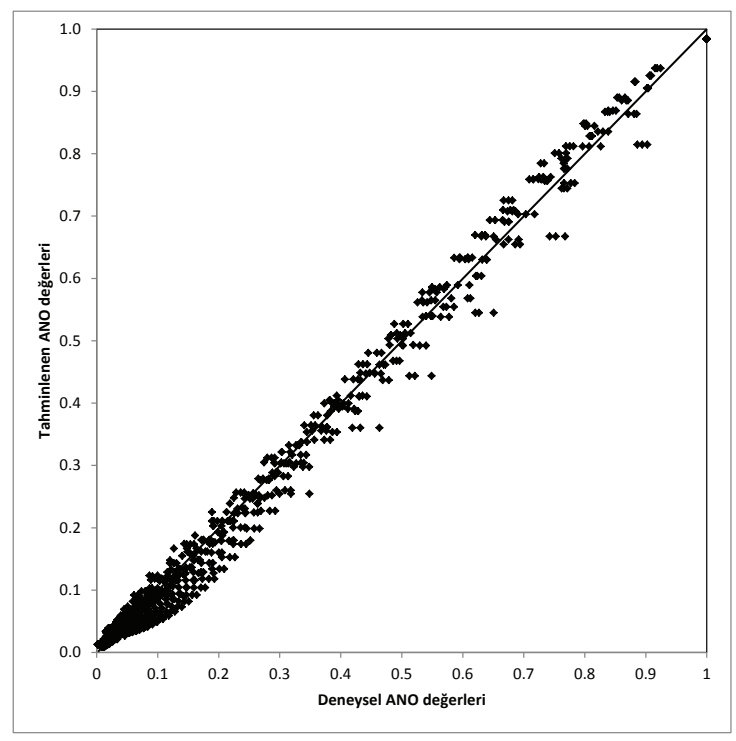

Figure 5- Comparison of the experimental and predicted moisture ratio for the developed model

Şekil 5- Deneysel ve gelişstirilen model yardımıyla tahminlenen nem oranı değerlerinin karşılaştırılması

\section{Conclusions}

In this study, the drying behavior of artichoke leaves was investigated. Drying artichoke leaves at constant $1.2 \mathrm{~m} \mathrm{~s}^{-1}$ drying air velocity down to approximately $10 \%$ (wet basis) moisture content at air temperature of $40,50,60$ and $70{ }^{\circ} \mathrm{C}$ in the dryer lasted about $3.50,1.54,1.04$ and $0.71 \mathrm{~h}$ respectively. It is evident from the experimental data there is no constant rate drying period.

For describing the drying behavior of artichoke leaves, seven models were applied to the drying process. The different mathematical drying models considered in this study were evaluated according to the $R^{2}, R M S E, \chi^{2}$ and $P$ to estimate drying curves. The correlation coefficients of all of the models considered in this study was found to be close to 
each other while the RMSE, $\chi^{2}$ and $P$ values were the smallest once the Midilli et al model was used. Based on these findings the Midilli et al model was selected and a drying constant model of $k$ as a function of the temperature of drying air and airflow velocity was developed and a final model was proposed. The drying model explains the drying of artichoke leaves the air temperature $T$ range of $40{ }^{\circ} \mathrm{C} \leq T \leq 70{ }^{\circ} \mathrm{C}$ and $0.6 \mathrm{~m} \mathrm{~s}^{-1} \leq \mathrm{V} \leq 1.2 \mathrm{~m} \mathrm{~s}^{-1}$ drying airflow velocity. The predictions by the Midilli et al model were found to be in good agreement with the data obtained in the laboratory.

Wang et al (2003) found that the phenolic content of artichokes did not significantly change during the drying at a temperature of $70{ }^{\circ} \mathrm{C}$ and freeze-drying. Using this argument, it can be stated that artichoke leaves can be dried at either 60 or $70{ }^{\circ} \mathrm{C}$ if a faster drying is needed.

\section{Acknowledgements}

The authors would like to acknowledge the financial support provided by the Ege University Research Fund.

\section{References}

Akgun N A \& Doymaz I (2005). Modelling of olive cake thin-layer drying process. Journal of Food Science and Technology 68: 455-461

Alibas İ (2012). Asma yaprağının (Vitis vinifera L.) mikrodalga enerjisiyle kurutulması ve bazı kalite parametrelerinin belirlenmesi. Tarm Bilimleri Dergisi-Journal of Agricultural Sciences 18: 43-53

Alonso M R, García M C, Bonelli C G, Ferraro G \& Rubio M (2006). Validated HPLC method for cynarin determination in biological samples. Acta Farm. Bonaerense 25(2): 267-70

Artnaseaw A, Theerakulpisut S \& Benjapiyaporn C (2010). Drying characteristics of Shiitake mushroom and Jinda chili during vacuum heat pump drying. Food and Bioproducts Processing 88: 105-114

Baysal T, Içier F, Ersus S \& Yildiz H (2003). Effects of microwave and infrared drying on the quality of carrot and garlic. Eur. Food Res. Technology 218: 68-73

Bundy R, Walker A F, Middleton R W, Wallis C \& Simpson H C R (2008). Artichoke leaf extract (Cynara scolymus) reduces plasma cholesterol in otherwise healthy hypercholesterolemic adults: A randomized, double blind placebo controlled trial. Phytomedicine 15: $668-675$

\begin{tabular}{|c|c|}
\hline \multicolumn{2}{|c|}{ Abbreviations and Symbols } \\
\hline$A, B, C$ & constants \\
\hline$a, b, c, g, h, n$ & dimensionless coefficients in the drying models \\
\hline$k$ & drying coefficients in the drying models, $\mathrm{h}^{-1}$ \\
\hline$M_{0}$ & initial moisture content, dry basis $\left(\mathrm{kg}\right.$ water $\left.\mathrm{kg}^{-1} \mathrm{dm}^{-1}\right)$ \\
\hline$M_{e}$ & equilibrium moisture content, dry basis $\left(\mathrm{kg}\right.$ water $\left.\mathrm{kg}^{-1} \mathrm{dm}^{-1}\right)$ \\
\hline$M R$ & moisture ratio, dimensionless \\
\hline$M R_{\text {exp }}$ & experimental moisture ratio, dimensionless \\
\hline$M R_{\text {pre }}$ & predicted moisture ratio, dimensionless \\
\hline$M_{t}$ & moisture content at any time, dry basis $\left(\mathrm{kg}\right.$ water $\left.\mathrm{kg}^{-1} \mathrm{dm}^{-1}\right)$ \\
\hline$N$ & total number of observations \\
\hline$n_{1}$ & number of constants \\
\hline$P$ & mean relative percent error \\
\hline$R^{2}$ & coefficient of determination \\
\hline$R M S E$ & root mean square error \\
\hline$T$ & air temperature, ${ }^{\circ} \mathrm{C}$ \\
\hline$t$ & time, $\mathrm{h}$ \\
\hline$V$ & air velocity, $\mathrm{m} \mathrm{s}^{-1}$ \\
\hline$\chi^{2}$ & chi-square \\
\hline
\end{tabular}

Tarım Bilimleri Dergisi - Journal of Agricultural Sciences 20 (2014) 415-426 
Demir V, Gunhan T \& Yagcioglu AK (2007). Mathematical modelling of convection drying of green table olives. Biosystems Engineering 98(1): 47-53

Doymaz İ (2013). Determination of infrared drying characteristics and modelling of drying behaviour of carrot pomace. Tarim Bilimleri Dergisi-Journal of Agricultural Sciences 19: 44-53

FAO (2013). FAOSTAT Agricultural Database Web Page Retrieved in December, 18, 2013 from. http://faostat3. fao.org/faostat-gateway/go/to/download/Q/QC/E

Figiel A (2010). Drying kinetics and quality of beetroots dehydrated by combination of convective and vacuum-microwave methods. Journal of Food Engineering 98: 461-470

Hawlader M N A, Chou S K \& Chua K J (1997). Development of design charts for tunnel dryers. International Journal of Energy Research 21(11): 1023-1037

Krokida M K, Maroulis Z B \& Kremalis C (2002). Process design of rotary dryers for olive cake. Drying Technology 20(4-5): 771-788

Menges H O \& Ertekin C (2006). Thin layer drying model for treated and untreated stanley plums. Energy Conversion and Management 47(15-16): 2337-2348

Midilli A \& Kucuk H (2003). Mathematical modelling of thin layer drying of pistachio by using solar energy. Energy Conversion and Management 44(7): 11-22

Nicoleti J F, Telis-Romero J \& Telis V R N (2001). Airdrying of fresh and osmotically pre-treated pineapple slices: Fixed air temperature versus fixed temperature drying kinetics. Drying Technology 19: 2175-2191

Özdemir M \& Devres Y O (1999). The thin layer drying characteristics of hazelnuts during roasting. Journal of Food Engineering 42: 225-233

Panchariya P C, Popovic D \& Sharma A L (2002). Thin layer modelling of black tea drying process. Journal of Food Engineering 52: 349-57

Sacilik K \& Elicin A K (2006). The thin layer drying characteristics of organic apple slices. Journal of Food Engineering 73(3): 281-289
Sanchez-Rabaneda F, Jauregui O, Lamuela-Raventos R M, Bastida J, Viladomat F \& Codina C (2003). Identification of phenolic compounds in artichoke waste by high-performance liquid chromatography-tandem mass spectrometry. Journal of Chromatography A 1008: 57-72

Shimoda H, Ninomiya K, Nishida N, Yoshino T, Morikawa T, Matsuda H \& Yoshikawa M (2003). Anti-hyperlipidemic sesquiterpenes and new sesquiterpene glycosides from the leaves of artichoke (Cynara scolymus L.): structural requirement and mode of action. Bioorganic \& Medicinal Chemistry Letters 13(2): 223-228

Silva E M, Da Silva J S, Pena R S \& Rogez H (2011). A combined approach to optimize the drying process of flavonoid-rich leaves (Inga edulis) using experimental design and mathematical modelling. Food and Bioproducts Processing 89: 39-46

Strumillo C \& Kudra T (1986). Drying: Principles, Applications and Design. Gordon and Breach Science Publishers, New York

Temple S J \& van Boxtel A J B (1999). Thin layer drying of black tea. Journal of Agricultural Engineering Research 74: 167-176

Togrul I T \& Pehlivan D (2003). Modelling of drying kinetics of single apricot. Journal of Food Engineering 58: $23-32$

Wang M, Simon J E, Aviles I F, He K, Zheng Q \& Tadmor Y (2003). Analysis of antioxidative phenolic compounds in artichoke (Cynara scolymus L.). Journal of Agricultural and Food Chemistry 51: 601608

Yaldiz O \& Ertekin C (2001). Thin layer solar drying of some vegetables. Drying Technology 19(3): 583-596

Yaldiz O, Ertekin C \& Uzun H I (2001). Mathematical modelling of thin layer solar drying of Sultana grapes. Energy 26(5): 457-465

Zhu X F, Zhang H X \& Lo R (2005). Antifungal activity of Cynara Scolymus L. extracts. Fitoterapia 76: 108111 